\title{
Ideological illusions, human rights and the right to education: the in(ex)clusion of the poor in post-apartheid education
}

\section{Anne Becker and Petro du Preez}

\begin{abstract}
Against the background of global concern about the political and social consequences of human rights, this article uses an ideological lens to explore the (non)existence of the right to education in South Africa. We argue that post-apartheid education actively (re)normalises the in(ex)clusions of the poor in education within neo-liberal capitalist human rights frameworks. Data from the NRF funded project Human Rights Literacy: A quest for meaning (Roux, 2012) indicate that student-teachers are aware of the ideological illusion presented in the Real and contrasting educational realities. We conclude by arguing for the need to assume common responsibility for the in(ex)clusions of the poor in education. The importance of human rights literacies cannot be underestimated in this regard. Human rights literacies open spaces in which student-teachers in common responsibility can engage with issues such as poverty and in(ex)clusions in education.
\end{abstract}

\section{Introduction}

The preamble to The South African Constitution (RSA, 1996a hereafter Constitution) describes South Africa as "a democratic and open society" and states that the Constitution (RSA, 1996a) aims to improve "the quality of life of all citizens" and free "the potential of each person". Globally, inclusive education as a basic human right is entrenched in various international declarations and conventions (Christie, 2010).

In line with global and local declarations and conventions, the Department of Basic Education (DoE), had since 1994, promulgated several South African laws and policies in this regard. These include: The South African Schools Act, No 84 (RSA, 1996c), the National Education Policy Act 1996, Act No. 27 of 1996 (RSA, 1996b), White Paper 6 on Inclusive Education (DoE, 2001a), the Manifesto on Values, Education and Democracy (DoE, 2001b), the Guidelines for Inclusive Learning Programmes (DoE, RSA, 2005), the Strategy for Racial Integration (DoE, RSA, 2006), the Bill of Responsibilities 
for the Youth of South Africa (DoE, RSA, 2008) and Implementation Guidelines to Rights-based Education (DoE and UNICEF South Africa, 2008) (Becker, De Wet and Van Vollenhoven, 2015). However, despite specific provisions in the South African Bill of Rights (1996) as to the right to education and numerous education laws and policies, scholars such as Nkonyane (2014) and Soudien (2010) pose that post-apartheid education perpetuates historic patterns of marginalisation in South Africa resulting in South Africa remaining one of the most unequal societies in the world. This article aims to explore the ideological illusion of full inclusion in education, expressed by student-teachers and the influence thereof on their understanding of the (non)realisation of the right to education and resulting marginalisation and in(ex)clusions. In this article, the 'who and what' of in(ex)clusion are the poor.

Recent critique on human rights can be traced back to the inception of human rights during the Enlightenment. The Declaration of the Rights of Man and of the Citizen (1789, hereafter DRMC) grounded in a quest to protect and preserve individual choice, autonomy, identity and subjectivity, resulted in liberal individualism still dominating understandings of human rights today (Becker, 2013). Arendt (1966) argued that the atrocities of the Holocaust had been easy to perpetrate because the DRMC (1789) had never been philosophically questioned. In the aftermath of World War II, in a renewed quest to protect individual freedom, dignity and equality, the Universal Declaration of Human Rights (1948, hereafter UDHR) was drafted. The twenty-seven articles of the UDHR (1948) were divided between the three human rights values that crystalised after the French Revolution, namely dignity, liberty and equality which also advanced the notion of the three generation of rights (Becker 2012; Weston, 1984).

The right to education forms part of second generation social, cultural and economic rights grounded in the socialist tradition. It serves as a counterpoint to first generation civil and political rights. Second generation rights speak to violations resulting from capitalism and conceptions of liberty used to rationalise and validate such violations (Weston, 1984). Second generation rights are claims to social justice and equity and demand intervention from the state for their realisation (Weston, 1984). After 1994 and in order to redress previous educational inequality and a growing demand for education, the new ANC government focussed education policies on open access to education for all children. This commitment, however is circumscribed by neoliberal macroeconomics and statements of the need for fiscal discipline in education 
finance. At present, the South African government provides 12 years of free education for all children. In practice, however, parents contribute, indirectly and directly, for the education of their children (Weber, 2002). Despite numerous policies aimed at full inclusion, access to education remain largely dependant on financial means (Christie, 2010).

In light of the above, this article uses an ideological lens to explore the processes inherent to the (non)realisation of the right to education, with specific reference to post-apartheid South Africa. The lack of substantive rights to education in South Africa illustrates the ideological underpinnings of human rights as well as the paradox of (non)existing human rights. This article does not speak to the effects of neo-liberalism and capitalism on the nature and processes of education and teaching-learning. It does not aim to speak of the poor or for the poor. It speaks to both the possession paradox of human rights and the capitalist illusion (as narrated by student-teachers) of full inclusion in the abstract universal right to education, masking this paradox. The possession paradox of human rights holds that although one might have the abstract right to education, one might, at the same time, not have the right to education (Donnelly, 2007). The poor may be theoretically fully included in the right to state provision of basic education (Constitution 1996), but in South Africa this has been normalised as a limited right.

Conceding that there are many systemic and structural socio-economic, political and historical reasons for in(ex)clusions in education, we argue that post-apartheid education actively constructs, normalises and masks in(ex)clusions within neo-liberal human rights frameworks and capitalist illusions. To do so, we draw on Zizek's (2008) conceptualisation of ideology as manifesting in the Real and social reality. The ideological illusion, presented in the Real, of full inclusion by abstract written rights and of neoliberal capitalist education as eradicating poverty is in stark contrast to social and educational realities of in(ex)clusions. In conclusion we argue that all South Africans, as the subjects of rights, should assume common responsibility for the in(ex)clusions of the poor in education and stress the importance of teaching-learning towards human rights literacies in this regard.

We pose the following research questions: How do the dynamics of the Real and social and educational reality manifest in post-apartheid education? and What are their influences on the in(ex)clusion of the poor in post-apartheid education? 


\section{Methodological considerations and contextualisation}

The NRF funded project, Human Rights Literacy: a quest for meaning (Roux and Du Preez, 2013) was concerned with human rights literacy in teacher education. Poverty and in(ex)clusions in education was not the focus of the research. The research focused on understandings and literacies in regard to the following: gender/sexuality, culture, religion, social justice, values and the implications thereof for curriculum. This article explores the possession paradox of human rights (specifically socio-economic rights), the ideological illusion masking the paradox and the narration of the ideological illusion of full inclusion in the right to education, narrated by student-teachers.

Three strategies were used to collect qualitative and quantitative data: a 'walk-about', a survey and small focus group discussions (Becker, De Wet and Parker, 2014; Roux and Du Preez, 2013). First, in order to probe understandings of human rights and develop questions for the survey, a 'walk-about' was conducted on three university campuses in two provinces. Convenience sampling was used to select $\mathrm{n} 80$ participants (Gillham, 2008; Flick, 2009). During the 'walk-about' students were stopped on campus and asked four questions: Do you agree with the concept of human rights; What do you regard as the most important human right? What are human rights? and How do you 'live out' human rights? (Becker et al., 2014)

Purposive sampling (Cresswell, 2013; Pidgeon and Henwood, 2004) was used for the survey phase of the data collection process. Three levels of sampling were employed during this phase. First, three institutions were selected. Secondly, six campuses (sites) in four provinces were chosen by means of stratified purposive sampling (Becker et al., 2014). The aim was to identify subgroups and facilitate comparisons (Ritchie, Lewis and Elam, 2009). Site 1 is a metropolitan campus where the majority of students are Zulu-speakers. Site 2 is a metropolitan campus with students from diverse linguistic and cultural backgrounds. Site 3 is a rural campus where most of the students are Afrikaans. Site 4 is in a semi-rural area and most students are Afrikaans. Site 5 is situated in a metropolitan area so the student population is linguistically, ethnically and culturally diverse. At Site 6, a rural campus, most students are Setswana speakers (Becker et al., 2014). The final decision was to focus on first and final year pre-service teachers in teacher education programmes at the six sites. A total of n1086/4953 student-teachers completed the survey. 
After the survey, small focus-group discussions were conducted on the six sites to validate the data that had been collected and to review the literature, ontologies and epistemologies (Roux and Du Preez, 2013). A total of n68/1086 students were selected by means of snow-ball sampling (Cresswell, 2013; Gillham, 2008). During the first meeting discussions were initiated by asking one question: Do you think human rights exist? During the second meeting scenarios drafted by the researchers regarding human rights violations in terms of gender, religion, culture and first generation rights were discussed. At Site $1-\mathrm{n} 18$ student-teachers participated, at Site 2 only n2, at Site 3-n13, at Site 4-n14, at Site 5-n11 and at Site 6-n9. Student-teachers participating in the focus groups discussions were between 18 and 28 years old and spoke six of the 11 official languages (Becker et al., 2014). Focus group discussions were digitally recorded and transcribed verbatim by the researchers.

This article uses a neo-Marxist lens to explore the effect of neo-liberal capitalism on human rights and post-apartheid education, particularly the in(ex)clusion of the poor in education. Neo-Marxism is part of a wide range of critical theories viewing globalisation as premised on power and hegemony and marketised education as serving capitalist interests (Shields, 2013). For the purpose of this article, only question 30 from the survey is used. Selected excerpts from the data generated by the 'walk-about' and the first focus group discussions are analysed using discourse analysis (Potter, 2004). Data are referenced in terms of the data source: 'walk-about' refers to responses obtained by this strategy. Focus-group references indicate the site, year group and meeting: s1 $44 \mathrm{~m} 2$ refers to data from Site 1(s1), fourth year (y4), second meeting (m2).

Before presenting the data, we briefly explore the manifestation and dynamics of neoliberal capitalism in the Real, social and educational reality.

\section{The Real, social reality and the right to education}

At the inception of human rights, it was believed that the human rights values of freedom, dignity and equality were self-evident and inalienable and that the legalisation of abstract universal human rights will guarantee these values (Becker, 2012). During the last decade, comments such as "the concept of 
human rights fits with the life of the well-off much more accurately (and conveniently) than those of the badly off" (Chi, 2005) and "by accepting 'human' rights we have agreed to alienate our right to the state to decide for us what and who is human" (Neocosmos, 2006), indicate that human rights have become a morality of power (Becker, 2012). The criticism of the hollowness of abstract written universal rights centres on exclusions, the failure to acknowledge the Other, identity politics, the moral and political core of universal rights and the ideological premise of such rights (Zembylas and Bozalek, 2014; Cistelecan, 2011; Žižek, 2005; Rancière, 2004). Scholars such as Žižek (2005) and Ranciere (2004) contend that the politics of human rights serve imperialist and colonialist economic interests in the guise of tolerance or humanitarian intervention or aid.

Schweickart (2011, p.3) describes the spectre of globalised capitalism as follows: "infinitely alluring, mysteriously powerful, savagely unequal and profoundly irrational." The notion that capitalism works, is challenged by scholars such as Žižek (2014; 2011; 2009a; 2009b, 2008), Piketty (2014) and Schweickart (2011). Social divisions, inequality and in(ex)clusions are historic and ongoing. Marx and Engels (2008, p.3) contend that "the history of all hitherto existing society is the history of class struggles" and Piketty (2014) argues that there is little evidence that the share of labour in the national income in the twenty-first century has increased since the eighteen and nineteenth centuries. This is partly because "if there was ever a system which enchanted its subjects with dreams (of freedom, of how your success depends on yourself, of the run of luck which is just around the corner, of unconstrained pleasures...), then it is capitalism" (Žižek, 2009a, p.26). The hegemony of neo-liberal capitalism extends the logic of marketisation to all spheres of social life such as politics, health and education (see Žižek, 2014).

There are various and contested notions of the Real. Both Sayer (2000) and Baxter (1987) critique and depart from Habermas' 'two-level' theory of modern societies integrating action-theoretical and systems-theoretical sociological perspectives. The distinction between system/life-world has largely been identified with Habermas (Sayer, 2000). This model of system / life-world interchange, grounds Habermas' account of modern capitalist societies. Baxter (1987) argues that Habermas' model of system/life-world does not adequately account for the interchange between the two and that the distinction between the two leads to misconceptions regarding economic, political and administrative systems. For Sayer (2000) systems and life-worlds are dimensions of the modern society and do not correspond to particular 
physical spaces. Systems, however, are always culturally embedded in and dependent on life-worlds. Žižek's (2008) contribution to this debate lies within his conceptualisation of the Real and social reality and how ideologies are shaped and reproduced in the movement between the Real and social reality. Although Žižek is described as a Marxist, there are great differences between his Marxism and that of Anglo-American academics. Žižek (2008) finds in the Manifesto the recognition of the destruction which capitalism produces. He however argues that the theoretical error made by Marx does not lie in the analysis of capitalism's destruction but in the faith that the contradictions of capitalism could be overcome. The dream of a spiral of productivity unchecked by contradictions is one of capitalism's own ideological fantasies, Žižek contends (Harpham, 2003).

Žižek (2008) borrows the term the Real from Lacan. He focusses on Lacan's link between the Real and the construction of fantasies. While symptoms (in psychoanalyses) are interpreted as unconscious formations, fantasies are constructed as responses to the Real (Samuels, 2008). For both Žižek and Lacan, the Real does not have a positive-substantial consistency; it describes a socio-symbolic process (Noys, 2010). In the Sublime Object of Ideology (2008), Žižek's notion of ideology as an objectified fantasy-structure correlates with the Real as the unpresentable and unknowable traumatic kernel; it is what we desire but can never know or grasp (Noys, 2010; De Kesel, 2004). The initial clear opposition between the Real and the Symbolic order (the order of language and law) in Žižek's earlier conceptualisation of the Real, shifted towards a conceptualisation of the Real, not as the external hard kernel, but a permutation of the symbolic (the domain of language and law) in his later works (Noys, 2010).

Within a globalised Real, meaning is de-totalised and emptied. Meaning-less truths such as that everyone has equal access to education, are continually normalised and presented as if they were social reality (ŽIžek, 2009a; 2014). In social reality, according to Žižek (2008), humans are actively involved in the production processes of capitalism: they act, re-act and inter-act on the Real and the 'truths' presented in the Real. The ideological illusion of capitalism is thus social reality (not a representation or abstraction of social reality). The Marxist definition of ideology: "they do not know it, but they are doing it" does not apply to capitalism, so Žižek (2008, pp.27,30) rephrases it to "they know very well what they are doing but still keep on doing it". Although we know that the 'truths' presented as social reality are meaningless, and we know the interests they serve, we choose not to renounce them 
(Žižek, 2008). In South Africa, we structure social and educational realities on the ideological illusion that everyone has equal access to education. The illusionary power of a neoliberal capitalist utopia, of democracy, human rights and dreams of success thus continually (re)normalises educational in(ex)clusions, class struggles, and the loss of freedom and equality (Žižek, 2009a).

The abstract written rights in the Constitution (1996) fully include the formerly excluded in economic and educational progress and development. Furthermore, the right to education is globally presented as the 'solution' to poverty, inequality, marginalisation and social exclusions (Christie, 2008). Educational policies based on the abstract written right to education assume that policies can ensure that every child is fully included in education and in the 'solution' to poverty. Inclusion in and exclusion from education are, however, not bipolar concepts (Sayed, 2003). In(ex)clusion is the process of defining and constituting the included as the 'ideal' and the excluded as needing special measures to be fully included (Sayed, 2003). Paradoxically, the very measures which are intended to include the poor (the Other) differentiate, divide and cast the poor out (Popkewitz, 2009). Such measures furthermore reflect a "pathology of individual and group failure" (Sayed, 2003, p.4), which implies that poor people have only themselves to blame for their situation (Christie, 2008).

Capitalism's global reach "is grounded in the way it introduces a radical class division across the entire globe, separating those protected by the sphere of capitalism from those outside the sphere of capitalism" (Žižek, 2014, p.63). In risk societies the utopian illusion sells fears and insecurities and presents dreams of equality, free choice and full democracy as the solution (see Žižek, 2005). The ethical illusion which tolerance and capitalist charity and pity afford, protects us from social reality but simultaneously deny us the possibility of being responsible for the poor. Capitalist charity keeps the poor fully in(ex)cluded in the capitalist illusion. Their full in(ex)clusion remains crucial to capitalist reproduction, because as Žižek (2009b, p.20) poses: "the thing itself [capitalism] is the remedy against the threat it poses." Within a neoliberal capitalist human rights framework, the poor are the subjects of humanitarian aid and in education, the subjects of interventions and special measures, rather than the subjects of human rights or the right to education.

Arendt (1966, p.299) argues that the conception of universal human rights, "based on the assumed existence of a human being as such", broke down 
when the right-less in their "abstract nakedness of being human," were excluded from being the subjects of human rights in the concentration camps. In revisiting the question of human rights and the subjects of human rights, Rancière (2004) concludes that there are two forms of rights: written rights implying the possession paradox of human rights (the [non]existence of rights) and the rights of those who decide to use their rights and structure moments of dissensus in political spaces. Both Žižek (2005) and Rancière (2004) suggest that the possibilities of human rights (and the right to education) lie in the gap between (non)existing rights when humans structure dissensus. Dissensus is premised on humanity's own universality as political agents of social reality and as the subjects of human rights (Cistelecan, 2011). This, we argue becomes possible when human solidarity is enacted by assuming common responsibility.

For Arendt (2003), assigning moral or legal responsibility to individuals for human rights violations such as in(ex)clusions is not a solution. For her the answer lies in common responsibility. This rests on two criteria: I am responsible for something I have not done and I am a member of a collective from which I cannot disengage myself (Arendt, 2003). As a member of humanity, I am responsible for all the misery that every other member(s) of humanity causes. I am fully and collectively responsible for, and a possible victim of, the (non)existence of human rights. This kind of responsibility is only possible in political spaces (Arendt, 2003). When the ideal of human solidarity is purged of pity, guilt and tolerance, it demands that all humans assume global political responsibility for humanity's right to have rights. Although this is an almost unbearable burden, the price for non-responsibility is "considerably higher" (Birmingham, 2006, Arendt, 2003, p.150).

The price of non-responsibility in this context is the continual normalisation of the in(ex)clusions of the poor from the capitalist sphere and the right to education. The poor remain invisible, without the right to be seen and recognised as equals by equals. They are not part of the 'we' of humanity (Birmingham, 2006). They can therefore not be the subjects of human rights or, in the context of this article, the subjects of the right to equal educational opportunities. Assigning or shifting moral or legal responsibility for the in(ex)clusion of the poor to government or humanitarian agencies results in everyone being guilty and nobody being guilty (see Arendt, 2003). Within common responsibility the poor are fully included in the 'we' of humanity. It becomes possible to renounce the ideological illusion and, in solidarity, to structure dissensus in political spaces. In the next section, data is presented 
regarding the (non)realisation of the right to education resulting in the in(ex)clusion of the poor.

\section{The right to education and the in(ex)clusion of the poor}

The 1994 promise of a better life for all, reinforced by the abstract written right to education in the Constitution (1996) featured in the answers of student-teachers. During the 'walk-about' participants were asked what they regarded as the most important human right. The right to education featured prominently in their responses. Of the $\mathrm{n} 71$ participants who answered this question, $\mathrm{n} 24$ chose the right to education, $\mathrm{n} 21$ the right to equality, $\mathrm{n} 13$ the right to freedom, $\mathrm{n} 9$ the right to life and $\mathrm{n} 4$ the right to dignity, as the most important human rights. Of the $\mathrm{n} 24$ students who chose education $\mathrm{n} 17$ assumed a link between neoliberal capitalist education, the alleviation of poverty and the possibilities of employment and success (inclusion in a marketised society). The following excerpts provide examples:

Education. So we can succeed in life (walk-about)

The right to education. . . because education fights poverty (walk-about)

The right to basic education. Education opens opportunities, doors and minds. If exercised adequately it can combat poverty (walk-about)

... why to be educated, because everything is about money and education (walk-about)

The survey dealt with perceptions of human rights, human rights and gender/sexuality, human rights and society, human rights constructs, human rights and religion/culture and human rights and education (mostly curriculum issues). The only question concerning human rights/poverty and education was question 30 :

When poverty influences the ability of children to access education, are you of the opinion that they are denied the right to education? 
$\mathrm{n} 750$

\begin{tabular}{|l|l|l|}
\hline Answer choices & Responses & \\
\hline I agree somewhat & $18.80 \%$ & 141 \\
\hline I disagree somewhat & $8.80 \%$ & 66 \\
\hline Neither agree nor disagree & $6.13 \%$ & 46 \\
\hline Totally disagree & $19.87 \%$ & 149 \\
\hline Fully agree & $46.40 \%$ & 348 \\
\hline Total & 750 & \\
\hline
\end{tabular}

Of the student-teachers who answered this question n348 fully agreed, and $\mathrm{n} 141$ agreed somewhat, that poverty influences access to education and the right to education. This question only concerns access to education (not quality of education and/or access to quality education) and indicates that $34.8 \%$ of participants did not regard poverty as a barrier to the realisation of the right to education. Forty-six point four percent of student-teachers, however, indicated that poverty definitely influences substantive rights to education.

During the first meeting with the small focus groups, student-teachers were only asked one question: Do you think human rights exist? Thirty-four of 68 student-teachers $(50 \%)$ at all six sites qualified their yes answer to this question by pointing to the non-realisation of socio-economic rights. Examples include:

Participant 1F: . . let's say my grandmother in Qwa-qwa, she is so poor they don't even have water they have to walk miles to get water. (s5y1m1)

Participant 2F: ... I think people who do not have a job, a month's ... And the other thing is grandmothers take taxis to get their grant and I think they should get some free transport to get their grants. . . (s1y1m1b)

Participant 4F: . . Like I mean how many people in South Africa don't have proper sanitation, and don't have running water, and don't have, ... I mean how many homeless people are there. . . (s6y4m1) 
Participant 1M: . . that women - she may give birth in the floor of the clinic, but the poster may be there - telling her that everyone has the right to what, what, what. . (s6y1m1)

Participant 5F: . . Sometimes the rights of children do not exist in our country, because they don't get what they have. (s4y4m1a)

Seventeen student-teachers from Sites 1, 3, 4, 5 and 6 described the right to education as a manifestation of the existence of human rights:

Participant 1F: ... I think that human rights exist because the government says that every child, every learner are supposed to be at school and get a free education. (s $1 \mathrm{y} 1 \mathrm{~m} 1 \mathrm{~b})$

Participant 2F: ... Yes because you have the right to education. $(\mathrm{s} 3 \mathrm{y} 4 \mathrm{~m} 1)$

Participant 3F: ... I think it does exist, because we see people exercising their rights on a daily basis. For example, at schools and the right to education. (s4y4m1a)

Participant 2F: ... I would say like. . let me take my right to education. I see that it resolves around my rights because I have a right to education. . . ( $55 \mathrm{y} 4 \mathrm{~m} 1)$

Participant 2M: . . . Well I do think that human rights exist. . because there is a law that says that everyone has rights to basic education, even if you are in rural areas - so you must study, so, that is proof. (s6ylm1)

However, 16 student-teachers on Sites 1, 3, 4, 5 and 6, voiced their concern about the (non)existence of the right to education, arguing that the right to education depend on having money to pay for education:

Participant 3F: . . Some children do not have the right to go to school. At some schools like in rural areas children do not have the right to go to school or they do not have money to help them to go to school. (s1y1m1b) 
Participant 4F: . . but then we look at the right to education, everyone has a right to education, but then there are people who cannot pay financially for it and then it is only that, that right is taken away from you. (s3y4m1)

Participant 3F: .. If you look at the right to education, what about those poor kids that don't have textbooks or anything, where is their right to be educated?. . Their right to education is not actually there. . . (s4y1m1)

Participant 5F: . . for instance, education, there are schools but the level of education it is so low, it's so low. We were doing practical recently, God it's a mess. Everything, everything is not in its place, the teachers are lazy the Principal himself is not responsible for the school. . . Why have I the right to education if I am not given the education that I deserve. Why? ( $55 \mathrm{y} 1 \mathrm{~m} 1)$

Participant 4F: ... Because there are people who still are, who are there in places where they don't have access to education. ( $\mathrm{s} 6 \mathrm{y} 1 \mathrm{~m} 1)$

At Site 3 two student-teachers saw the in(ex)clusion of the poor from education because of class differences as inevitable or a given:

Participant 2F: Yes, because you have a right to education, but everyone is in different classes. (s3y4m1)

Participant 2M: I think it [human rights] is applied correctly [within educational systems]. I think if you look at private schools. All are not on the same level. So the education system is designed in such a way that everyone could be accommodated. So you can't be here [showing with his/her hand a lower level] and then you are in a private school, because then you can't afford it, and if you can't afford it, then your child should be in a state school. So, everyone has equal rights, but it is about status as well. (s3y1m1)

Student-teachers'definition of who and what the poor are, influenced the lens through which they 'saw'poverty and the resultant in(ex)clusions. It also influenced how they understood and made sense of poverty and pathologies of failure regarding the poor (see Sayed, 2003). According to studentteachers from Site 1, the poor were those people who live in shacks (s1y1m1a 
and s1y1m1b), not even tin houses, houses built with mud (s1ylm1a). They live in rural areas $(\mathrm{s} 1 \mathrm{y} 4 \mathrm{~m} 1 \mathrm{a})$. Children of the poor have no food, no clothes to wear and the only time when they get something to eat is when someone brings them a meal to eat. Other than that they are starving (s1y4m1a). At site 5, one student-teacher described the poor as living in underdeveloped areas $(\mathrm{s} 5 \mathrm{y} 1 \mathrm{~m} 1)$.

Failure was to be expected, because obviously [the poor] are less educated (s5y1m1). Student-teachers at Sites 1, 3 and 5 argued that the poor did not know about rights (s5y1m1; s1y4m1; s3y4m1), do not believe in human rights $(\mathrm{s} 1 \mathrm{y} 4 \mathrm{~m} 1)$ and did not have the means to bring to book those who violate their rights (s $1 \mathrm{y} 4 \mathrm{~m} 1 ; \mathrm{s} 2 \mathrm{y} 1 \mathrm{~m} 1 ; \mathrm{s} 3 \mathrm{y} 4 \mathrm{~m} 1)$. At Site 4 and 6 studentteachers posed that the poor had to resort to stealing to support themselves and their families (s4y1m1; s6y4m1). At Sites 1, 5 and 6 student-teachers situated the poor in distant geographical place and space; in rural areas (s1y1m1a; s1y4m1a; s5y1m1), in underdeveloped areas (s5y1m1) and in shacks (s1y1m1a) and houses built with mud (s1y1m1a). They also seemed to actively construct an emotional distance from the poor in the use of phrases such as those people and poor people (s1y1m1; s6y4m1; s5y1m1).

Seven student-teachers from Sites 5, 3 and 6 argued that claiming rights was the responsibility of every individual and the poor could/should claim their rights:

Participant 4F: I think for me it's like I can have a voice to speak because if I know what the constitution says, human rights say, then I can go this is my right to get educated, then I know how to use it and how it protects me... ( $55 \mathrm{y} 1 \mathrm{~m} 1)$

Participant 1F: ... then you will surely say but I want to attend school, no matter what happens. . . Then someone will reach out and say we are here, especially the state police department or so. So it actually depends on person to person if you will. . . activate. . your human rights. (s3ylm1)

While student-teachers from Sites 3, 5 and 6 posed that the poor should claim their rights six student-teachers from Sites 4 and 6 expressed frustration and resentment towards the poor and the effects of poverty on South African society. 
Participant 3F: ... they [are] just make[ing] babies there, ja, we can't afford them but they get $R 350$ [social grants] per child per month so lekker.... (s6y4m1)

Participant 2F: .. .most of our [South Africa's] problems are due to the reason of poverty $(\mathrm{s} 6 \mathrm{y} 4 \mathrm{~m} 1)$

Participant 3F: . . we pay, we pay for their [the poor] electricity, for their food and their houses (s6y4m1)

Participant 5F: . . And sometimes their parents, the government gives them a grant for their children, but the parents take the money for booze or something (s4y4m1a)

In response to a question from one of the researchers regarding responsibility for the poor, eight student-teachers from Sites 1 and 6 argued that they/we should/could be responsible but then qualified their answers by arguing that they were not solely responsible or not responsible as such. They held government and business responsible:

Participant 3F: Not responsible as such, but we should also help and contribute to the poor. ( $1 \mathrm{y} 4 \mathrm{~m} 1 \mathrm{~b})$

Participant 1F: We are not solely responsible but we should also contribute and help. (s1y4m1b)

Participant 5M: We should all help and local businessmen they should help. (s1y4m1b)

Participant 2F: ... and learners must get someone to support them to go to school and further education. Government should support them.

(s1y1m1a)

Participant 1F: .. It starts with the government. They do all the policies and everything. . . they should be enforcing it. (s6y4m1)

Participant 4F: . . But then once again look where we are, apartheid happened how many years ago and they [government] still haven't got those basic rights in. ( $66 \mathrm{y} 4 \mathrm{~m} 1)$ 


\section{Ideological illusions, educational realities, the poor and the right to education: discussion}

During the first focus group meeting fifty percent of student-teachers described the possession paradox of human rights with specific reference to the (non)realisation of socio-economic rights. Rancière (2004, p.302) explains that human rights are held by all humans (the subjects of rights) "who have not the rights that they have and have the rights that they have not". Written rights, such as the right to education, express the abstract ideal of education for everyone but simultaneously imply the (non)existence of the right to education and the in(ex)clusion of everyone in education.

Student-teachers regard the right to education as an important manifestation of human rights and socio-economic rights (n24: walk-about; n17: first small focus-group discussion) The underlying assumption of the illusionary narrative of post-apartheid education is that neo-liberal capitalist education results in the eradication of poverty, supported by the abstract written right to education for everyone in the Constitution (1996), were evident in the answers of students during the walk-about. Of the $\mathrm{n} 71$ who answered the question as to what they regard as the most important human right, $\mathrm{n} 17$ linked neo-liberalist education to the illusion of eradicating poverty and possibilities of success.

The ideological illusion, links the abstract ideal of full inclusion in education and the eradication of poverty as the social reality. However, this is a meaning-less truth within the frame of globalised capitalism and the saturation of human rights and education by neo-liberal capitalism. Although the poor are fully included in the abstract written right to education, they are simultaneously separated and excluded from those protected and included in the sphere of capitalism (see Žižek, 2014). The neo-liberal capitalist policies and measures which purportedly include the poor in education, differentiate, divide and cast them out (see Popkewitz, 2009).

Žižek (2008) argues that capitalism is social reality in which we know the Real is an illusion but we remain involved in the production processes of capitalism. Student-teachers (n16/68) who participated in the small focus group discussions expressed concern with the (non)realisation of the right to education due to financial constraints. In answer to Q30 in the survey $65.20 \%$ of student-teachers (fully agree or agree somewhat) indicated that they regard 
poverty as a possible barrier to substantive rights to education. Studentteachers (n17/68) on the other hand, also explained the realisation of the right to education as the manifestation of the existence of human rights. They furthermore argued that it is the responsibility of every individual to claim their rights (n7) and that the poor are the responsibility of government and business (n8).

Six student-teachers expressed feelings of frustration, dissonance and resentment towards the poor. In trying to make sense of their resentment, frustration, conflict and dissonance, student-teachers assigned responsibility for the poor to government, the business sector and others with power, illustrating Arendt's notion that in such contexts, everyone is guilty and nobody is guilty (see Arendt, 2003.) There is an irony in the assumption that government and those in power are responsible: within neo-liberal capitalist societies, local businesses and those in power rely on capitalist principles to stay in power and maintain or increase their wealth. Capitalism relies on this assumption to re-produce itself: "the thing itself [capitalism] is the remedy against the threat it poses" (Žižek, 2009b, p20).

The poor are not included in the sphere of neo-liberal capitalist education. They are referred to as those people. They are from distant emotional spaces and geographical places: rural areas and in underdeveloped areas. They are obviously less educated. They are the responsibility of someone who might bring them food and clothes. They are the responsibility of those (government, the business sector and others with power) who rely on capitalist principles, structures and systems to enrich themselves and stay in power. The in(ex)clusion of the poor from education illustrate the possession paradox of human rights, and the neo-liberal capitalist illusion masking this.

\section{Conclusion and recommendations}

Within neo-liberal capitalist human rights frameworks the poor are positioned as the subjects of interventions, aid and special measures. They are not the subjects of the right to education. Children whose parents can pay for education are included and presented as the 'ideal' and those without financial means are excluded and are the objects of special measures. The processes through which poor children are in(ex)cluded from the capitalist sphere and education are advanced within educational and social reality by children, 
teachers, parents and administrators acting and re-acting on the ideological illusion. The illusionary 'good story' of full inclusion in post-apartheid education is continually fed, engendering the hope that the right to education will translate into prosperity and equality (Van Zyl, 2014). This often ends in great despair (ibid.).

It is within the intersection of (non)existing rights that all South Africans should assume common responsibility, dissolve the illusion and structure political spaces and moments of dissensus by insisting on the full realisation of the right to education. Within such spaces, humans as political agents become the subjects of universal human rights. The paradox of the (non)existence of universal abstract written rights runs parallel to the paradox of humans in solidarity, acting on the premise of their own universality as political agents of social and educational reality and not on the premise of universal abstract written rights (see Žižek, 2005).

Faculties of Education should direct teaching-learning towards common responsibility and sensitise student-teachers to the processes at work in neoliberal capitalist human rights frameworks that continually in(ex)clude the poor from education. The saturation of both education and human rights by neo-liberalism and liberal individualism however, present some obstacles. We pose that the importance of teaching-learning towards human rights literacies cannot be underestimated in this regard. Literacy as a cognitive skill include knowledge of human rights documents, the remedies available and the values inherent to human rights (and the right to education). Literacy as a social practice alludes to how humans in common responsibility act, re-act and inter-act on abstract human rights within educational contexts. (cf. Simmonds, 2014). Finally, human rights literacies enable students and teachers to engage with issues such as poverty, gender, religion and social justice within human rights frameworks (Roux and Becker, 2015; Simmonds, 2014).

\section{Acknowledgement}

This work is based on a research project supported by the National Research Foundation (NRF) of South Africa. The grant holder acknowledges that opinions, findings and conclusions or recommendations expressed in any publication generated by the NRF-supported research are those of the author(s), and that the NRF accepts no liability whatsoever in this regard. 


\section{References}

Arendt, H. 1966. The origins of totalitarianism. Cleveland: The World Publishing Company.

Arendt, H. 2003. Responsibility and judgment. New York: Schocken Books.

Baxter, H. 1987. System and life-world in Habermas's "Theory of Communicative Action". Theory and Society, 16(1): pp.39-86.

Becker, A. 2012. Identity premised on equality of difference as a fundamental human right. In Roux, C. (Eds), Safe spaces. Human rights education in diverse contexts. Rotterdam: Sense, pp.83-96.

Becker, J.A. 2013. Curriculum and intra-dialogic spaces: consciousness and becoming in identity construction based on human rights values. $\mathrm{PhD}$ thesis. Potchefstroom: North West Univerity.

Becker, A., De Wet, A. and Parker, G. 2014. Moving towards understanding one an-other: Cornelia Roux on religion, culture and human rights. Journal for the Study of Religion, 27(1): pp.234-266.

Becker, A., De Wet, A. and Van Vollenhoven, W. 2015. Human rights literacy: moving towards rights-based education and transformative action through understandings of dignity, equality and freedom. South African Journal of Education, 35(2): pp.1-12.

Birmingham, P. 2006. Hannah Arendt and human rights. The predicament of common responsibility. Bloomington: Indiana University Press.

Chi, J. 2005. Taking the reasons for human rights seriously. Political Theory, 33(2): pp.243-265.

Christie, P. 2008. Changing schools in South Africa. Opening the doors of learning. Johannesburg: Heinemann.

Christie, P. 2010. The complexity of human rights in global times: the case of the right to education in South Africa. International Journal of Educational Development, 30: pp.3-11. 
Cistelecan, A. 2011. Which critique of human rights? Evaluating the postcolonialist and the post-Althusserian alternatives. International Journal of Žižek Studies, 5(1): pp.1-13.

Cresswell, J.W. 2013. Qualitative inquiry and research design. Choosing among five approaches. 3rd ed. London: Sage Publication.

De Kesel, M. 2004. Act without denial: Slavoj Žižek on totalitarianism, revolution and political act. Studies in east European thought, 56(4). The many faces of Slavoj Žižek's radicalism, pp.299-334.

Department of Education, 2001a. Education White Paper 6: Special Needs Education (Building an Inclusive Education and Training System). Pretoria: Department of Education. Available at http://www.education.gov.za/LinkClick.aspx?fileticket=gVFccZLi\%2ftI\%3d \&tabid=191\&mid=484. Accessed 14 September 2014 .

Department of Education, 2001b. Manifesto on Values, Education and Democracy. Pretoria: Department of Education. Available at http://www.dhet.gov.za/Reports\%20Doc\%20Library/Manifesto\%20on\%20Va lues,\%20Education\%20a nd\%20Democracy.pdf. Accessed 11 March 2015.

Department of Education, Republic of South Africa (RSA) 2005. Guidelines for inclusive learning programmes (Draft). Available at http://www.education.gov.za/LinkClick.aspx?fileticket $=\mathrm{mBxVzYkx} 8 \mathrm{fA} \% 3 \mathrm{~d}$ $\underline{\text { \&tabid }=452 \& \mathrm{mid}=1036}$ Accessed 14 September 2014.

Department of Education, RSA 2006. Strategy for racial integration. Pretoria: Department of Education. Available at http://v1.sahistory.org.za/pages/hands-on-classroom/classroom/pages/projects /PDF/Racial-Strategy.pdf Accessed 14 September 2014.

Department of Education, RSA 2008. A bill of responsibilities for the youth of South Africa. Available at http://www.education.gov.za/LinkClick.aspx?fileticriket=zofmUDfVRM8\%3 D\&tabid=93\&mid=1130. Accessed 14 September 2014. 
Department of Education and United Nations Children's Fund (UNICEF) RSA 2008. Implementation guidelines: safe and caring child friendly schools in South Africa. Pretoria: Department of Education and UNICEF South Africa.

Donnelly, J. 2007. The relative universality of human rights. Human Rights Quarterly, 29: pp.281-306.

Flick, U. 2009. An introduction to qualitative research. $4^{\text {th }}$ ed. London: Sage.

Gillham, B. 2008. Small scale social survey methods. London: Continuum International Publishing Group.

Harpham, G.G. 2003. Doing the impossible: Slavoj Žižek and the end of knowledge. Critical Inquiry, 29(3): pp.453-485.

Marx, C. and Engels, F. 2008. The communist manifesto. London: Pluto Press.

Neocosmos, M. 2006. Can a human rights culture enable emancipation?

Clearing some theoretical ground for the renewal of a critical sociology. South African Review of Sociology, 37(2): pp.356-379.

Nkonyane, V. 2014. Poverty and education in postdemocratic South Africa. In Okeke, C., Van Wyk, M. and Phasha, N. (Eds), Schooling, society and inclusive education: an Afrocentric perspective. Cape Town: Oxford University Press, pp.151-175.

Noys, B. 2010. The horror of the Real: Žižek's modern gothic. International Journal of Žižek studies, 4(4): pp.356-405

Pidgeon, N., Henwood, K. 2004. Grounded Theory. In Hardy, M and Bryman, A. (Eds), Handbook of data analysis. London:Sage. pp625-649

Piketty, T. 2014. Capital in the twenty-first century. Padstow: TJ International Ltd.

Popkewitz, T.S. 2009. Curriculum study, curriculum history, and curriculum theory: the reason of reason. Journal of Curriculum Studies, 41(3): pp.301-319. 
Potter, J. 2004. Discourse analysis. In Hardy, M. and Bryman, A. (Eds), Handbook of data analysis. London: Sage, pp.607-625.

Rancière, J. 2004. Who is the subject of human rights. The South Atlantic Quarterly, 103: pp.297-310.

Ritchie, J., Lewis, J. and Elam, G. 2009. Designing and selecting samples. In Ritchie, J. and Lewis, J. (Eds), Qualitative research practice. A guide for social science students and researchers. London: Sage, pp.1-23.

Roux, C. 2012. Human rights literacy: a quest for meaning. NRF project proposal. http://www.nwu.ac.za/node/19644

Roux, C., Becker, A. 2015. Human rights literacy: a quest for meaning. European Wergeland centre statement series. October 2015. http://theewc.org/statement/human.rights.literacy.the.quest.for.meaning/

Roux, C.D., Du Preez, P. 2013. Human rights literacy: a quest for meaning. Available at http://www.nwu.ac.za/sites/www.nwu.ac.za/files/files/Hreid\%20cv\%27s/Hum an\%20rights \%20literacya $\% 20$ quest $\% 20$ for $\% 20$ meaning blog $\% 20$ en $\% 20$ website.pdf. Accessed 14 February 2014.

Republic of South Africa, 1996a. Constitution of the Republic of South Africa No. 108 of 1996. Pretoria: Government Printer. Available at http://www.gov.za/sites/www.gov.za/files/images/a108-96.pdf. Accessed 12 March 2015.

Republic of South Africa, 1996b. National Education Policy Act, 1996 (Act No. 27 of 1996). Pretoria: Government Printer. Available at http://www.acts.co.za/nationaleducation-policy-act996/index.html?assp assessment policy in the general education and train ing band grades $\mathrm{r}$ to 9 and abet.php. Accessed 12 March 2015.

Republic of South Africa, 1996c. South African Schools Act, 1996 (Act No 84 of 1996). Pretoria: Government Printer. RSA 2000. Promotion of Equality and Prevention of Unfair Discrimination Act 4 of 2000. Pretoria: Government 
Printer. Available at http://www.justice.gov.za/legislation/acts/2000-004.pdf. Accessed 12 March 2015.

Samuels, R. 2008. Lacan after Žižek: self-reflexivity in the outomodern enjoyment of psychoanalysis. International Journal of Žižek Studies, 2(4): pp.145-160.

Sayed, Y. 2003. Educational exclusion and inclusion: key debates and issues. Perspectives in Education, 21(3): pp.1-12.

Sayer, A. 2000. System, lifeworld and gender: associational versus counterfactual thinking. Sociology, 34(4): pp.707-725.

Schweickart, D. 2011. After capitalism. Second Edition. Plymouth: Rowman \& Littlefield Publishers Inc.

Shields, R. 2013. Globalization and international student mobility: a network analysis. Comparative Education Review, 57(4): pp.609-636.

Simmonds S. 2014. Mapping the curriculum-making landscape of religion education from a human rights education perspective. Journal of the Study of Religion, 27: pp.129-153.

Soudien, C. 2010. What to teach the natives: a historiography of the curriculum dilemma in South Africa. In Pinar, W.F. (Ed.), Curriculum studies in South Africa: intellectual histories and present circumstances. New York: Palgrave, pp.22-45.

Van Zyl, G.M. 2014. The 'nervous condition' of neo-liberated higher education students. South African Journal of Higher Education, 28(5): pp.1663-1679.

Weber, E. 2002. Shifting to the right: the evaluation of equity in the South African government's development and education policies, 1990-1999. Comparative Education Review, 46(3): pp.261-290.

Weston, B.H. 1984. Human Rights. Human Rights Quarterly, 6(3): pp.257-283. 
Zembylas, M. and Bozalek, V. 2014. A critical engagement with the social and political consequences of human rights: the contribution of the affective turn and posthumanism. Acta Academica, 46(4): pp.29-47.

Žižek, S. 2005. Against human rights. New Left Review, 34: pp.115-131.

Žižek, S. 2008. The sublime object of ideology. London: Verso.

Žižek, S. 2009a. First as tragedy, then as farce. London: Verso.

Žižek, S. 2009b. Violence. London: Profile Books Limited.

Žižek, S. 2011. Living in the end times. London: Verso.

Žižek, S. 2014. Trouble in paradise. From the end of history to the end of capitalism. London: Penguin.

Anne Becker

Petro du Preez

Faculty of Educational Sciences

North West University

anne.becker@nwu.ac.za

petro.dupreez@nwu.ac.za 